\title{
UNOBSERVABLE EFFECTS AND SPEED OF ADJUSTMENT TO TARGET CAPITAL STRUCTURE
}

\author{
Bolaji Tunde Matemilola \\ Universiti Putra Malaysia \\ Bany Ariffin Amin Noordin \\ Universiti Putra Malaysia \\ Wan Azman Saini Wan Ngah \\ Universiti Putra Malaysia \\ Annuar Md Nassir \\ Universiti Putra Malaysia
}

\begin{abstract}
The paper investigates whether unobservable firm-specific effects such as managerial ability is a major component of the target capital structure. We apply the system generalized method of moments that accounts for unobservable firm-specific effects. Our results reveal that unobservable firm-specific effects such as managerial ability are a major component that explains most of the cross-sectional variation in firms' capital structure in Malaysia.
\end{abstract}

Keywords: Capital Structure; Unobservable Effects; System GMM; Malaysia.

\section{INTRODUCTION}

Over the years, capital structure studies have identified reliable factors such as profit, size, non-debt tax shield, fixed assets and market-to-book ratio as some of the variables that affect firms' capital structure (Flannery and Hankins, 2013; Nunkoo and Boateng, 2010; Frank and Goyal, 2009). However, recent empirical evidence on capital structure has challenged the reliability of these factors with the argument that unobservable firm-specific factors which are time invariant explain most of the cross sectional variation in firms' capital structure (Hanousek and Shamshur, 2011; Lemmon et al., 2008). Chang and Dasgupta (2011) show that unobservable firm-specific fixed effects alone contribute as much as 95 percent of the explained variation in the capital structure using simulation approach on sample data of firms from the United States. Responding to the issue of unobservable firm-specific factors, Graham et al (2011) recognized managerial ability as a component of the unobservable firm-specific factors that was previously identified as important. They find that time invariant manager fixed effects explain majority of the variation in executive compensation, in Canada.

Corresponding author: Department of Accounting and Finance, Faculty of Economics and Management, Universiti Putra Malaysia, Serdang, Malaysia,. Tel: 603-8946 7735, email: bany@upm.edu.my 
Unlike previous studies, we investigate whether unobservable factors such as top managers' managerial ability explain most of the crossectional variation in the Malaysian firms's capital structure. The paper contributes to the capital structure research in the way we apply the standard methodology to investigate the importance of the firm-specific effects using Malaysian listed firms samples. Specifically, we apply the system GMM to estimate a model that is correctly specified versus a model that is miss-specified, but account for unobservable firm-specific effects such as top managers' ability. In Malaysia, Bontis et al. (2000) recognised the importance of top managers as a component of human capital. They cconclude that human capital is important, regardless of industry type. Bontis et al. (2000) also noted that top managers developed their skills through education. In this study, we account for top managers' ability using the panel generalized method of moments (GMM). Specifically, the study applies the System-GMM that control for firm specific effects such as top manangers' ability, in the level equation.

Moreover, Malaysia is a fast emerging market that has shown some growth in recent times according to the World Bank (2013) stability reports. However, Malaysian has certain characteristics that are different from what is obtainable in developed countries. Specifically, the size of the Malaysian capital market (in terms of market capitalization) is smaller than developed countries such as the USA and Switzerland but the size of the Malaysian capital market is relatively bigger compared to Brazil, India, Thailand and Canada. Moreover, corporate transparency (in terms of information disclosure and quality of accounting standards) is lower in Malaysia compared to countries such as the UK, Finland and Singapore, but corporate transparency is higher in Malaysia than in countries such as India, Thailand, South Africa and Brazil. Oztekin and Flannery (2012) report these differences in market capitalization and level of corporate transparency across selected countries including countries mentioned above and Malaysia.

These differences in level of capital market development and corporate transparentcy among others could make transaction costs lower in the developed countries capital markets compared to developing countries (e.g. Malaysia) capital markets. Differences in the countries level of capital market development infuence transaction costs. Transaction costs in turn affect the speed of adjustment to firms' target capital structure. Moreover, capital structure research is relevant to Malaysia that has a functioning capital market and bond market.

The objective of this paper is to investigate whether unobservable firm-specific effects is a major component of the target capital structure in Malaysia. Unlike previous studies, the paper argues that if unobservable firm-specific effects such as top managers'ability are the major component of firms' target capital structure, there should be no much difference between the speed of adjustment in a model that omits firm-level determinants of capital structure and year fixed effects, but account for only the unobservable firm-specific effects, and a model that include firm-level determinants, year fixed effects, and account for unobserved firm-specific effects.

The rest of the paper is organized as follows: section 2 explains the methodology, section 3 describes data, section 4 discusses the results, while section 5 concludes the paper. 


\section{METHODOLOGY}

The dependent variables are the ratio of total debt to total assets and ratio of long-term debt to total assets. We use the book value of debt because it better captures the active adjustment behavior of a firm's capital structure compared to market debt that captures adjustment to market fluctuation. We follow Oztekin and Flannery (2012) and apply the standard partial adjustment model to capture the dynamic adjustment toward the target capital structure, that is:

$$
\operatorname{Debt}_{i t}-\operatorname{Debt}_{i t-1}=\lambda\left(\operatorname{Debt}^{*}{ }_{i t}-\operatorname{Debt}_{i t-1}\right)+\mu_{i t}
$$

Where $\lambda$ is the average speed of adjustment (SOA) to the target capital structure each period for all the sample firms, Debt* ${ }_{i t}$ is the target debt level while Debt $_{i t}$ and Debt $_{\text {it-1 }}$ are the current and lagged 1 period debt ratios, respectively. The model assumes that the firm has a target debt level and adjust if there is a deviation from the target debt level. Full adjustment occurs when $\lambda=1$ while $\lambda=0$ means there is no adjustment. In the partial adjustment model, the actual adjustment of debt should be between 0 and 1. The target debt or capital structure is unobservable, so, we proxy it with the fitted values from a regression of observed debt on a set of firms' specific determinant of the target capital structure (Lemmon et al 2008; Oztekin and Flannery, 2012; Matemilola and Ahmad, 2015).

$$
\operatorname{Debt}_{i t}=\beta X_{i t-1}+\eta_{i}+\alpha_{t}+\mu_{i t}
$$

Where $X_{i t-1}$ represents the firm specific determinants of capital structure, $\eta_{i}$ and $\alpha_{t}$ are firm fixed effect and year fixed effects respectively. After we substitute the target debt or target capital structure from Equation (2) into the partial adjustment model in Equation (1) and rearranging the terms, the estimation in a single equation becomes:

$$
\operatorname{Debt}_{i t}=(1-\lambda) \operatorname{Debt}_{i t-1}+\lambda \beta X_{i t-1}+\eta_{i}+\alpha_{t}+\mu_{i t}
$$

Where the speed of adjustment (SOA) is equal to one minus the coefficient of the lagged debt $(1-\lambda) . X_{\text {it- } 1}$ is the set of variables that represent the determinants of the target capital structure from Equation (2). All the independent variables are lagged by one period to reduce the effects of endogeneity problem. In order to estimate the speed of adjustment (SOA), we apply the system generalized methods of moments (GMM). The system-GMM is believed to give better results compared to other approaches that use difference GMM or two stages least square methods (Flannery and Hankins, 2013). Specifically, in order to investigate whether unobservable firm-specific effects is a major component of target capital structure; the paper specifies the models below: 


$$
\begin{aligned}
\text { Debt }_{i t}= & (1-\lambda) \text { Debt }_{\text {it-1 }}+\lambda\left(\beta_{1}+\beta_{2} \text { FA }_{\text {it-1 }}+\beta_{3} \text { Profit }_{\text {it-1 }}+\beta_{4} \text { Size }_{i t-1}\right. \\
& \left.+\beta_{5} \text { Risk }_{\text {it }-1}+\beta_{6} \mathrm{GO}_{\mathrm{it}-1}+\beta_{7} \text { Ndts }_{\mathrm{it}-1}\right)+\eta_{\mathrm{i}}+\alpha_{\mathrm{t}}+\mu_{\mathrm{it}} \\
\text { Debt }_{\mathrm{it}}= & (1-\lambda) \text { Debt }_{\mathrm{it}-1}+\beta_{1}+\eta_{\mathrm{i}}+\mu_{\mathrm{it}}
\end{aligned}
$$

Where $\eta_{i}$ is the unobserved firm-specific effects, $\alpha_{t}$ is the year fixed effects, $\mu_{i t}$ is the error term, subscripts ' $i$ ' and ' $t$ ' represent firm and time period respectively. Blundell and Bond (1998) system generalized method of moment (GMM) is used to estimate the model. The paper lags the explanatory variable by one period and all the explanatory variables are treated as endogenous in the system-GMM estimation. The system GMM improves efficiency (Blundell and Bond, 1998). System-GMM combines difference instruments and level instruments in order to improve efficiency of the estimated parameters.

System-GMM combines equation in first difference and equation in level and system-GMM improves efficiency. However, system-GMM efficiency depends on the validity of additional moment's condition that the correlation between unobservable firm-specific effects in the level equation and the instruments in difference is equal to zero. Rather than one step, the paper uses two-step system-GMM because it uses the first-step errors to construct heteroskedasticityconsistent standard errors and it gives better results. The paper overcomes the instrument proliferation problem in System-GMM by restricting the number of instruments to two in each period.

One of the direct ways to investigate whether unobservable firm-specific effects is a major component of the target capital structure using a dynamic model specification is to examine the impact that unobservable firm-specific effects have on the estimated speed of adjustment (SOA). Specifically, if the unobservable firm-specific effects or time invariant factors (such as top managers' managerial ability) are the major component of firms' target capital structure, there should be no much difference between the speed of adjustment in model $3 b$ (that omits firm-level determinants of capital structure and year fixed effects, but account for only the unobservable firm-specific effects) and model $3 \mathrm{a}$ (that include firm-level determinants, year fixed effects, and account for unobserved firm-specific effects). Application of traditional ordinary least squares methods to estimate parameters are biased when there is combination of firm-specific effects and lagged dependent variable in the model specification. Therefore, this paper applies the system-GMM because it is recognized as one of the best method to estimate the parameters of the target capital structure determinants that include firm-specific effects and lagged dependent variable (Flannery and Hankins, 2013). System-GMM corrects for endogenous and reverse causality problem between variables using efficient instrumental variable techniques.

\section{DATA}

The data set consists of firms listed on Bursa Malaysia from 2000 to 2009. The data were extracted from the Datastream databases. The paper excluded the financial industry from our sample because their capital structure is different from non- financial listed firms. The paper 
uses the top 400 listed firms (based on market capitalization) on the Bursa Malaysia. Longterm debt (LD) is the ratio of long-term debt to total assets. Total debt (TD) is the ratio of total debt to total assets. The paper uses book value measures of debt because it is not affected by price fluctuation. Fixed assets (FA) are the ratio of fixed assets to total assets. Profit is the ratio of profit before interest and tax to total assets. Size is the log of total assets adjusted for the effect of inflation. Growth opportunity is the book value of total assets minus the book value of equity plus the market value of equity divided by book value of total assets. Non-debt-taxshield (Ndts) is the ratio of depreciation to total assets. The independent variables in both models are proxies commonly used in the literature (e.g. Flannery and Hankins, 2013; BanyAriffin, 2010; Nunkoo and Boateng, 2010 ).

\section{EMPIRICAL RESULTS}

Table 1A and 1B present the descriptive statistics and correlation results, respectively. The correlation results are generally low between the independent variables which suggest that there is little risk of multi-collinearity problem in the data. In order to achieve our objective, we directly investigate the impact that unobservable firm-specific effects have on the estimated speed of adjustment (SOA). The speed of adjustment (calculated as 1- $\lambda$ ) for the lagged coefficient of long-term debt and total debt ratios. Interestingly, we find that there is no much difference in the speed of adjustment between model $3 \mathrm{~b}$ that include only unobservable firm-specific effects and model $3 a$ that include firm-level determinants, year fixed effects and unobservable firm-specific effects.

Based on our results (Table 2 and 3), Malaysian firms have a target capital structure and they partially adjust to their long-run target capital structure which is consistent with Nunkoo and Boateng (2010) results for Canadian firms and Chong and Law (2012) results for five Asian countries excluding Malaysia. Furthermore, the results confirm that including time varying factors in the target capital structure specification has little effect on the estimated speed of adjustment (i.e. 0.388 vs. 0.300 and 0.386 vs. 0.288 ) for long-term debt and total debt respectively). Precisely, the results support Hanousek and Shamshur (2011) that argues that substantial changes in the economic environment do not affect the stability of capital structure. They also find that unobservable firm-specific effects are responsible for the cross-sectional variation in the firms' capital structure. Similarly, the results are consistent with Lemmon et al. (2008) findings that unobservable firm-specific effects are responsible for cross-sectional variation in firms' capital structure.

The adjustment speed is calculated as $(1-\lambda)$, where $\lambda$ refers to the value of the estimated coefficient of the lagged debt variable in the dynamic panel models. Firms that deviate from their optimal debt ratios will undertake an adjustment process to their optimal debt level. However, market imperfections such as transaction costs may prevent firms to adjust much faster to their optimal debt level. The adjustment speed (calculated as 1- $\lambda$ ) for the lagged coefficient of long-term debt ratio is $(1-0.662=0.338)$ and for lagged coefficient of total debt ratio is $(1-0.614=0.386)$. The adjustment speed to optimal debt level (lagged total debt ratio) is slow compared with Ozkan (2001) that reports adjustment speed (lagged total debt ratio) of 0.55 for UK firms, but it is faster compared with Lemmon et al. (2008) that report 
adjustment speed (lagged total debt ratio) of 0.25 for US firms. Similarly, adjustment speed to optimal debt level is faster in Malaysia compared with Oztekin and Flannery (2012) that report adjustment speed of 27.07 for South African firms, 24.20 for Thailand firms and an adjustment speed of 23.63 for Indian firms. Based on our results, Malaysian firms have optimal debt and they make an effort to partially adjust to their long-run optimal debt level. Furthermore, the results imply that there are costs that prevent Malaysian firms to adjust much faster to their long-run optimal debt level.

As control variable, profits are positively related to capital structure which support the tradeoff theory. These results contradict findings of Lemmon et al (2008), Frank and Goyal (2009), and Flannery and Hankins (2013) that profits are negatively related to firm debt in the United States. But the results is consistent with Nunkoo and Boateng (2010) findings that profits are positively related to firm debt in Canada. Also, as control variables, fixed assets is not significantly related to firm debt which is inconsisitent with Lemmon et al (2008), Frank and Goyal (2009), and Flannery and Hankins (2013) results that fixed assets are positively related to firm debt in the United States. Conversely, the results support Chang and Dasgupta (2011) who find that fixed is not significantly related to firm debt in Singapore. Turning to size variables, our results reveal that size is related to firm debt ratios. The negative relationship between debt and size is inconsistent with Flannery and Hankins (2013) and Matemilola and Ahmad (2015) empirical results that size is positively related to firm debt in United States and South Africa, respectively. Conversely, the results support Lemmon et al (2008), Hanousek and Shamshur (2011) who report negative relationship between size and firm debt ratio in United States and Central \& Eastern European countries, respectively. As a control variable, growth opportunity (GO) are positively related to debt ratio while non-debt tax-shield are significantly related to debt ratios. Likewise, risk is negatively related to debt and it is consistent with previous studies in the literature.

The reason for these differences in the study results could be because of the differences in size of capital market development and the level of corporate transparency and information asymmetry problem across countries that have been emphasized in our introduction. Fixed assets show insignificant results which are inconsistent with the trade-off theory prediction that fixed assets increases debt ratio. Interestingly, the paper finds a positive relationship between profits and both long-term debt and total debt ratios which also support the static trade-off theory that profitable firms use more debt because they have sufficient profits to repay principal plus interest (Nunkoo and Boateng, 2010). Moreover, profitable firms are less likely to go bankrupt because they can repay their principal amount plus interest as at when due. It is possible that banks placed more emphasis on firms' profitability to grant debt financing to firms in Malaysia. Firms that make stable profits and have the potential to sustain their profit level may obtain debt capital easily even if they do not disclose all information to banks.

Size variable is negatively related to debt ratios which is consistent with the pecking order theory that the issue of information asymmetry is less severe for large firms. Consequently, large firms could easily finance their investment directly from capital markets because asymmetric information is less likely to occur as investors can obtain more information about large firms than small firms. Growth opportunity is positively related to debt ratios. 
This supports the pecking order theory of Myers (1984) that suggests that firms with high growth prospects would need more debt to undertake profitable investments opportunities. In summary, traditional capital structure determinants are important, but they explain part, not all variations in capital structure of listed firms in Malaysian.

Table 1A: Descriptive Statistics

\begin{tabular}{ccccccccc}
\hline & LD & TD & FA & Profit & Size & NDTS & Risk & GO \\
\hline Mean & 0.17 & 0.25 & 0.70 & 0.52 & 0.08 & 0.04 & 2.77 & I.05 \\
Std.Dev. & 0.25 & 0.34 & 33.84 & 5.30 & 1.29 & 0.18 & 6.13 & 1.41 \\
\hline
\end{tabular}

Table 1B: Correlation Coefficients

\begin{tabular}{ccccccccc}
\hline & LD & TD & FA & Profit & Size & Ndts & Risk & GO \\
\hline LD & 1.00 & & & & & & & \\
TD & 0.99 & 1.00 & & & & & & \\
FA & -0.03 & -0.02 & 1.00 & & & & & \\
Profit & $0.09 * * *$ & $0.09 * * *$ & -0.01 & 1.00 & & & \\
Size & $-0.31 * *$ & $-0.32 * *$ & 0.01 & $-0.12 * * *$ & 1.00 & & \\
Ndts & $0.11 * *$ & $0.12^{* *}$ & -0.03 & $0.09 * * *$ & $-0.12 * * *$ & 1.00 & & \\
Risk & $-0.15^{* * *}$ & $-0.16^{* * *}$ & 0.03 & -0.01 & $0.13 * * *$ & $-0.081 * * *$ & 1.00 & \\
GO & $-0.05^{* *}$ & $-0.05^{* *}$ & 0.03 & -0.02 & $0.14 * * *$ & 0.03 & 0.02 & 1.00
\end{tabular}

Notes: ${ }^{\text {a }}$ Long-term debt (LD) is the ratio of long-term debt divided by book value of total assets. Total debt (TD) is the ratio of total debt divided by book value of total assets. Fixed assets (FA) is the ratio of fixed assets divided by book value of total assets. Profit is the ratio of profit before interest and tax divided by book value of total assets. Size is the $\log$ (book value of total assets), and it is adjusted for the effects of inflation. Ndts is the ratio of depreciation divided by book total assets. Risk is a yearly change in profit before interest and tax. Growth opportunity (GO) is measured as the book value of total assets minus the book value of equity plus the market value of equity divided by book value of total assets ${ }^{b} * *$ and $* * *$ indicate that correlation coefficients are significant at $5 \%$ and $1 \%$ level respectively.

Table 2: System generalized method of moment (GMM) results

\begin{tabular}{lcc}
\hline & Long term debt & Long-term debt \\
\hline Independent variable & GMM (System) & GMM (System) \\
Speed of Adjustment (SOA) & 0.338 & 0.300 \\
LD $_{\text {it-1 }}$ & $0.622^{* * *}$ & $0.700^{* * *}$ \\
Profit $_{\text {it-1 }}$ & $(31.58)$ & $(59.23)$ \\
Fixed assets & $0.002^{* * *}$ & \\
& $(6.93)$ & \\
& -0.000 & \\
\hline
\end{tabular}


Table 2: System generalized method of moment (GMM) results (cont)

\begin{tabular}{|c|c|c|}
\hline & Long term debt & Long-term debt \\
\hline Size $_{\text {it-1 }}$ & $\begin{array}{c}-0.522 * * \\
(-21.59)\end{array}$ & \\
\hline $\mathrm{Ndts}_{\mathrm{it}-1}$ & $\begin{array}{c}0.564 * * * \\
(17.26)\end{array}$ & \\
\hline Risk $_{\mathrm{it}-1}$ & $\begin{array}{c}-0.004 * * * \\
(-9.66)\end{array}$ & \\
\hline Growth Opportunity $(\mathrm{GO})_{\mathrm{it}-1}$ & $\begin{array}{c}0.002 * * * \\
(12.85)\end{array}$ & \\
\hline Year effects & Yes & No \\
\hline Firm-specific effects & Yes & Yes \\
\hline $2^{\text {nd }}$ order serial correlation ( $p$-value) & 0.308 & 0.328 \\
\hline Difference Sargan Test (p-values) & 0.203 & 0.410 \\
\hline \multicolumn{3}{|c|}{ 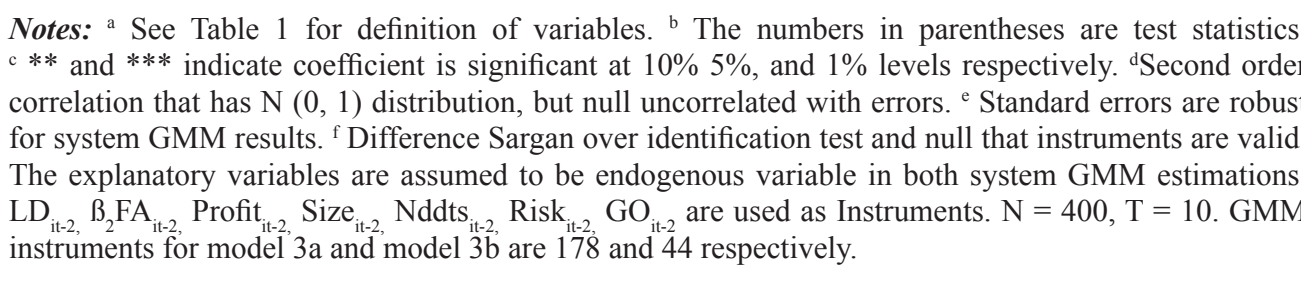 } \\
\hline Dependent variable & Total debt & Total debt \\
\hline Independent variable & GMM (System) & GMM (System) \\
\hline Speed of Adjustment (SOA) & 0.386 & 0.288 \\
\hline $\mathrm{TD}_{\mathrm{it}-1}$ & $\begin{array}{c}0.614 * * * \\
(24.79)\end{array}$ & $\begin{array}{c}0.702 * * * \\
(58.77)\end{array}$ \\
\hline Profit $_{\text {it-1 }}$ & $\begin{array}{c}0.003^{* *} \\
(6.74)\end{array}$ & \\
\hline Fixed assets $_{\mathrm{it}-1}$ & $\begin{array}{l}-0.000 \\
(-1.49)\end{array}$ & \\
\hline Size $_{\mathrm{it}-1}$ & $\begin{array}{c}-0.574 * * \\
(-23.27)\end{array}$ & \\
\hline $\mathrm{Ndts}_{\mathrm{it}-1}$ & $\begin{array}{c}0.810 * * * \\
(9.65)\end{array}$ & \\
\hline Risk $_{\mathrm{it}-1}$ & $\begin{array}{c}-0.001^{* *} \\
(-9.37)\end{array}$ & \\
\hline
\end{tabular}


Table 3: System generalized method of moment (GMM) results (cont)

\begin{tabular}{lcc}
\hline Dependent variable & Total debt & Total debt \\
\hline Growth Opportunity $(\mathrm{GO})_{\text {it-1 }}$ & $0.010^{* * *}$ & \\
& $(4.18)$ & \\
\hline Year effects & Yes & No \\
Firm-specific effects & Yes & Yes \\
$2^{\text {nd }}$ order serial correlation (p-value) & 0.281 & 0.333 \\
Difference Sargan Test (p-values) & 0.436 & 0.315 \\
\hline
\end{tabular}

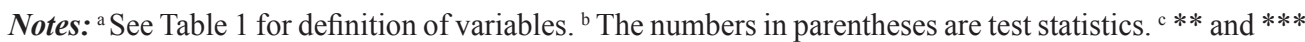
indicate coefficient is significant at $10 \% 5 \%$, and $1 \%$ levels respectively. ${ }^{\mathrm{d}}$ Second order correlation that has $\mathrm{N}(0,1)$ distribution, but null uncorrelated with errors. ${ }^{\mathrm{e}}$ Standard errors are robust for system GMM results. ${ }^{\mathrm{f}}$ Difference Sargan over identification test and null that instruments are valid. The explanatory variables are assumed to be endogenous variable in both system GMM estimations. $\mathrm{TD}_{\mathrm{it}-2,2} \beta_{2} \mathrm{FA}_{\mathrm{it}-2,2}$ Profit $\mathrm{it}_{\mathrm{it} 2 \text {, }}$ Size $_{\mathrm{it}-2,} \mathrm{Nddts}_{\mathrm{it}-2,}$, Risk $_{\mathrm{it}-2}, \mathrm{GO}_{\mathrm{it-2}-2}$ are used as Instruments. $\mathrm{N}=400, \mathrm{~T}=10$. GMM instruments for model $3 \mathrm{a}$ and model $3 \mathrm{~b}$ are 178 and 44 respectively.

\section{CONCLUSION}

This paper investigates whether unobservable firm-specific effects is a major component of the target capital structure. The system-GMM results show that there is no much difference in the speed of adjustment between model $3 b$ that include only unobservable firm-specific effects and model $3 \mathrm{a}$ that include firm-level determinants, year fixed effects and unobservable firmspecific effects. Our results imply that target capital structure may be time invariant and that existing determinants explain little variation in Malaysian firms' target capital structure. In order words, traditional capital structure determinants are important, but they explain part, not all variations in capital structure across listed firms in Malaysia. System-GMM is important to at least account for unobserved firm-specific effects that are time invariant. Unlike previous studies, this paper contributes to the capital structure research in the way we apply the standard methodology to investigate the importance of the firm-specific effects, such as managerial ability using Malaysian listed firms samples. Specifically, the paper applies the system-GMM to estimate a model that is correctly specified versus a model that is miss-specified, but account for unobservable firm-specific effects such as manangerial ability. Future research needs to place importance on the role of unobservable firm-specific effects (such as manangeria ability), especially in Malaysian context. An index measure of top manangers' managerial ability could be developed and management theory may be applied to explain the relationship between managerial ability and firms' capital structure (Matemilola et al, 2013).

\section{REFERENCES}

Bany-Ariffin, A. N. (2010). Disentangling the driving force of pyramidal firms capital structure: a new perspective. Studies in Economics and Finance, 27(3),195-210.

Blundell, R., \& Bond, S. (1998). Initial condition and moment restriction in dynamic panel data models. Journal of Econometrics, 87(1), 115-143. 
Bontis, N., Keow, W. C., \& Richardson, S. (2000). Intellectual capital and business performance in Malaysian industries. Journal of Interllectual Capital, 1(1), 85-100.

Chang, X., \& Dasgupta, S. (2011). Monte Carlo simulations and capital structure research. International Review of Finance, 11(1), 19-55.

Chong, T. T., \& Law, T. (2012). The capital structure adjustment of firms in five Asian economies. International Journal of Business and Society, 13(1), 1-18.

Flannery, M. J., \& Hankins, K. W. (2013). Estimating dynamic panel models in corporate finance. Journal of Corporate, 19 (February), 1-19.

Frank, M. Z., \& Goyal, V. K. (2009). Capital structure decisions which factors are reliably important? Financial Management, 38(1), 1-37.

Graham, J. R., Li, S. I., \& Qui, J. (2011). Managerial attributes and executive compensation. The Review of Financial Studies, 25(1), 144-186.

Hanousek., J., \& Shamshur, A. (2011). A stubborn persistent: Is the stability of leverage ratios determined by the stability of the economy. Journal of Corporate Finance, 17(5), 13601376.

Lemmon, M. L., Roberts, M. R., \& Zender, J. F. (2008). Back to the beginning: persistence and the cross-section of corporate capital structure. Journal of Finance, 63(4), 1575-1608.

Matemilola, B. T., \& Ahmad, R. (2015). Debt financing and importance of fixed assets and goodwill assets as collateral: dynamic panel evidence. Journal of Business Economics and Management, 16(2), 407-421.

Matemilola, B. T., Bany-Ariffin, A. N., \& McGowan, C. B. (2013). Unobservable effects and firm's capital structure determinants. Managerial Finance, 39(12), 1-18.

Myers, S. C. (1984). The capital structure puzzle. Journal of Finance, 39(3), 575-592.

Nunkoo, P. K., \& Boateng, A. (2010). The empirical determinants of target capital structure and adjustment to long-run target: evidence from Canadian firms. Applied Economic Letters, 17(10), 983-990.

Ozkan, A. (2001). Determinants of capital structure and adjustment to long-run target: evidence from UK company panel data. Journal of Business Finance and Accounting, 28(1-2), 175-198.

Öztekin, Ö., \& Flannery, M. J. (2012). Institutional determinants of capital structure adjustment speeds. Journal Financial Economics, 103(1), 88-112.

World Bank Group. (2013). World Development Report. Washington DC: The World Bank Group. 